\title{
Planning and formulation of environmental management system for Indian infrastructure projects
}

\author{
$C$ Akin $^{1, *}, R$ Samuel Devadoss ${ }^{2}$, and $V$ Vandhana Devi ${ }^{3}$ \\ ${ }^{1}$ Assistant Professor, Department of Civil Engineering, KCG College of Technology, Chennai- \\ 600097, India \\ ${ }^{2}$ Associate Professor, Department of Civil Engineering, Hindustan Institute of Technology and \\ Science, Chennai-603103, India \\ ${ }^{3}$ Associate Professor and Head of Department, Department of Civil Engineering, KCG College of \\ Technology, Chennai-600097, India
}

\begin{abstract}
Every year the impact on natural environment is more due to consumption of natural resources for large infrastructure and construction projects. Even though by implementing modern construction techniques and low cost effective materials the volume of impact reduction is not efficient. India is a country which has enormous natural resources and it has been utilized for large infrastructure and construction projects which makes an environmental impact. This present paper focuses on planning and formulation of Environmental Management System (EMS) to reduce the environmental impact due to large infrastructure and construction projects. The planning of EMS is done based on the environmental impact checklist provided by Ministry of Environmental and Forest Climate change (MoEF\&CC) under Government of India and the Formulation is done through PERT and CPM techniques which is to implement EMS in short duration to reduce environmental impact through large infrastructure and construction projects. Finally, the Planning and Formulation of EMS gives solution to reduce more volume of environmental impacts due to large infrastructure and construction projects.
\end{abstract}

\section{Introduction}

The Natural resources are the root cause for the aesthetics and sustainability of the earth. The basic needs of the living beings have to be fulfilled by the consumption of natural resources. As the modern era arrives more infrastructure development has been taking place all over the world in terms of Transportation systems, Tunnels, building constructions, etc. The infrastructure projects are the important consumers of natural resources especially through deforestation, Quarrying of huge rocks and mountains, Ground water consumption and finally it creates Environmental impact to Land, Air and Water Environment through Soil erosion, Air pollution and Carbon footprints which causes Global warming and Hazards. Every year the environmental impact increases due to consumption of more

${ }^{*}$ Corresponding author: akin.akin766@gmail.com 
natural resources for large infrastructure and Construction Projects. To reduce environmental impact Modern Construction techniques such as grouting and guniting techniques have evolved and low cost effective materials such as fly-ash, slag in replacement of cement has not proved its overall efficiency in reducing Environmental Impact. India is a Developing Country which has enormous amount of natural resources covering its huge mass of land area and with huge population. Infrastructure projects are an important source for the development of Nations growth through development of Roads, Highways, Dams and Tall and Multi storied buildings.

Therefore the utilization of natural resources is in need for the development of Infrastructure projects. Government of India has taken initiatives to mitigate environmental impact and provided guidelines through various research activities [1], [2]. Ministry of Environment, Forest and Climate Change (MoEF\&CC), Government of India has provided environmental impact checklist for reducing the environmental impact for large construction projects in many aspects considering the Land environment, Water environment, Air Environment, Aesthetics and Energy conservation techniques. The Environmental impact checklist of MoEF \&CC can be followed systematically by applying Environmental Management System (EMS) in which it saves time and cost of the project simultaneously [1], [2], [3]. EMS is an ISO 14001 concept which consists of Plan, Do, Check, Act also known as PDCA cycle which is used to save time, cost and energy [2], [4], [5]. In this Present Paper, Planning of Environmental Management System for infrastructure projects is done based on the Environmental impact checklist given by MoEF\&CC at Annexure 2 of form 1A for construction projects listed under item 8 of the schedule and Formulation of EMS is done through Programme Evaluation Review Technique (PERT) and Critical Path Method (CPM) to predict duration, variance, deviation and critical path which is used to implement EMS in short duration to reduce environmental impact through large infrastructure and construction projects [1], [2], [3]. Finally, the environmental impact checklist of MoEF \& CC with respect to proper planning and formulation of EMS the time, cost and energy can be saved and simultaneously it helps to reduce more volume of environmental impact for large infrastructure and construction projects in India.

\section{Methodology}

The methodology used here for planning and formulation of EMS in Indian Infrastructure and construction project has been classified typically into two steps; one is by planning and other by formulating. The first step is by Planning the stages of environmental impact due to an infrastructure and construction project with steps taken to mitigate by applying the EMS concept of Plan, do, check and act process. The stages of Environmental impact were obtained from the checklist provided in MoEF \& CC at Annexure 2 of form 1A for construction projects listed under item 8 of the schedule [1], [2], [6]. The Second step is by formulating the planned activities of the first step through PERT and CPM to implement the EMS process of reducing environmental impact within the estimated time duration and to predict the variance, standard deviations and the critical path of the overall process of applying EMS [2], [7].

\section{Results and discussion}

Based on the environmental impact checklist the first step planning was done to mitigate the impact due to a large infrastructure and construction project by applying the EMS process. Table 1 shows the method of planning based on environmental impact checklist by applying EMS. The stages of Environmental impact were obtained from the checklist 
provided in MoEF \& CC at Annexure 2 of form 1A for construction projects listed under item 8 of the schedule.

The Second step is by formulating the planned activities of the first step through PERT and CPM to implement the EMS process of reducing environmental impact within the estimated time duration and to predict the variance, standard deviations and the critical path of the overall process of applying EMS [2], [3], [8]. Table 2 shows the estimated time duration in days for implementing EMS. Where the optimistic time estimate was denoted as 'to', most likely time estimate was denoted as 'tm' and pessimistic time estimate was denoted as 'tp'. Table 3 shows the expected duration in days which was denoted as 'te' and the expected variance was denoted as ' $\sigma$ ' for applying EMS. Figure 1 shows the network diagram of the activities in the environmental impact checklist for the EMS process to reduce the environmental impact caused by a large infrastructure and construction project within the estimated time duration.

Table 1. Planning method based on Environmental impact checklist by EMS for construction projects.

\begin{tabular}{|c|c|c|c|c|c|}
\hline Activity & \begin{tabular}{|c|} 
Environmental \\
Impact Check list \\
\end{tabular} & Plan & Do & Check & Act \\
\hline 1 & Land Environment & Land use & Earthwork & Disturbances & Plant trees/ Solar \\
\hline 2 & Water Environment & $\begin{array}{c}\text { Water } \\
\text { Requirement }\end{array}$ & $\begin{array}{c}\text { Waste Water } \\
\text { treatment }\end{array}$ & Water balance & Water Recharge \\
\hline 3 & Vegetation & Local ecosystem & Site Modification & Threats & $\begin{array}{c}\text { Tree Plantation/ } \\
\text { Create Water } \\
\text { bodies }\end{array}$ \\
\hline 4 & Fauna & $\begin{array}{c}\text { Displacement of } \\
\text { fauna }\end{array}$ & Create barriers & Impacts & $\begin{array}{c}\text { Corridors/ fish } \\
\text { ladders }\end{array}$ \\
\hline 5 & Air Environment & $\begin{array}{l}\text { Atmospheric } \\
\text { concentration }\end{array}$ & $\begin{array}{c}\text { Transport } \\
\text { infrastructure }\end{array}$ & $\begin{array}{l}\text { Movement } \\
\text { Patterns }\end{array}$ & $\begin{array}{c}\text { Traffic } \\
\text { Management }\end{array}$ \\
\hline 6 & Aesthetics & Vicinity & Urban design & Obstruction & Landscaping \\
\hline 7 & $\begin{array}{l}\text { Socio-Economic } \\
\text { Aspects }\end{array}$ & $\begin{array}{c}\text { Local } \\
\text { population }\end{array}$ & $\begin{array}{c}\text { Social } \\
\text { infrastructure }\end{array}$ & Adverse effect & \begin{tabular}{|c|}
$\begin{array}{c}\text { Safeguard local } \\
\text { community }\end{array}$ \\
\end{tabular} \\
\hline 8 & Building materials & $\begin{array}{l}\text { Embodied } \\
\text { Energy }\end{array}$ & $\begin{array}{l}\text { Energy Efficient } \\
\text { process }\end{array}$ & Pollution & Recycle materials \\
\hline 9 & $\begin{array}{c}\text { Energy } \\
\text { Conservation }\end{array}$ & $\begin{array}{l}\text { Power } \\
\text { requirement }\end{array}$ & $\begin{array}{l}\text { Renewable } \\
\text { Energy } \\
\text { consumption }\end{array}$ & Energy balance & $\begin{array}{c}\text { Non conventional } \\
\text { energy } \\
\text { technologies }\end{array}$ \\
\hline 10 & $\begin{array}{c}\text { Environmental } \\
\text { Management Plan }\end{array}$ & $\begin{array}{c}\text { Construction } \\
\text { Phase }\end{array}$ & Operation Phase & $\begin{array}{c}\text { Environmental } \\
\text { Regulations }\end{array}$ & $\begin{array}{c}\text { Mitigation } \\
\text { Measures }\end{array}$ \\
\hline
\end{tabular}

Table 2. Estimated time duration (in days) for implementing EMS.

\begin{tabular}{|c|c|c|c|}
\hline Activity & to & tm & tp \\
\hline $\mathbf{1 - 2}$ & 3 & 4 & 5 \\
\hline $\mathbf{2 - 3}$ & 1 & 2 & 3 \\
\hline $\mathbf{2 - 4}$ & 2 & 3 & 4 \\
\hline $\mathbf{3 - 5}$ & 3 & 4 & 5 \\
\hline $\mathbf{4 - 5}$ & 1 & 3 & 5 \\
\hline $\mathbf{4 - 6}$ & 3 & 5 & 7 \\
\hline $\mathbf{5 - 7}$ & 4 & 5 & 6 \\
\hline $\mathbf{6 - 7}$ & 6 & 7 & 8 \\
\hline $\mathbf{7 - 8}$ & 2 & 4 & 6 \\
\hline $\mathbf{7 - 9}$ & 1 & 2 & 3 \\
\hline $\mathbf{8 - 1 0}$ & 4 & 6 & 8 \\
\hline $\mathbf{9 - 1 0}$ & 3 & 5 & 7 \\
\hline
\end{tabular}


Table 3. Expected duration in days and Expected Variance for implementation of EMS.

\begin{tabular}{|c|c|c|c|c|c|}
\hline Activity & to & $\mathbf{t m}$ & $\mathbf{t p}$ & $\begin{array}{c}\text { Expected duration } \\
\mathbf{t e}=\frac{\mathbf{t + m}+\mathbf{t p}}{\mathbf{6}}\end{array}$ & $\begin{array}{c}\text { Expected Variance } \\
\boldsymbol{\sigma}^{\mathbf{2}}=\left(\frac{\mathbf{t p - t o}}{\mathbf{6}}\right)^{\mathbf{2}}\end{array}$ \\
\hline $1-2$ & 3 & 4 & 5 & 4 & 0.11 \\
\hline $2-3$ & 1 & 2 & 3 & 2 & 0.11 \\
\hline $2-4$ & 2 & 3 & 4 & 3 & 0.11 \\
\hline $3-5$ & 3 & 4 & 5 & 4 & 0.11 \\
\hline $4-5$ & 1 & 3 & 5 & 3 & 0.44 \\
\hline $4-6$ & 3 & 5 & 7 & 5 & 0.44 \\
\hline $5-7$ & 4 & 5 & 6 & 5 & 0.11 \\
\hline $6-7$ & 6 & 7 & 8 & 7 & 0.11 \\
\hline $7-8$ & 2 & 4 & 6 & 4 & 0.44 \\
\hline $7-9$ & 1 & 2 & 3 & 2 & 0.11 \\
\hline $8-10$ & 4 & 6 & 8 & 6 & 0.44 \\
\hline $9-10$ & 3 & 5 & 7 & 5 & 0.44 \\
\hline
\end{tabular}

From table 3, it is observed that the expected duration of the activities in environmental impact checklist for EMS process implementation is 29 days which saves time and cost and simultaneously it reduces environmental impact for large infrastructure and construction projects.

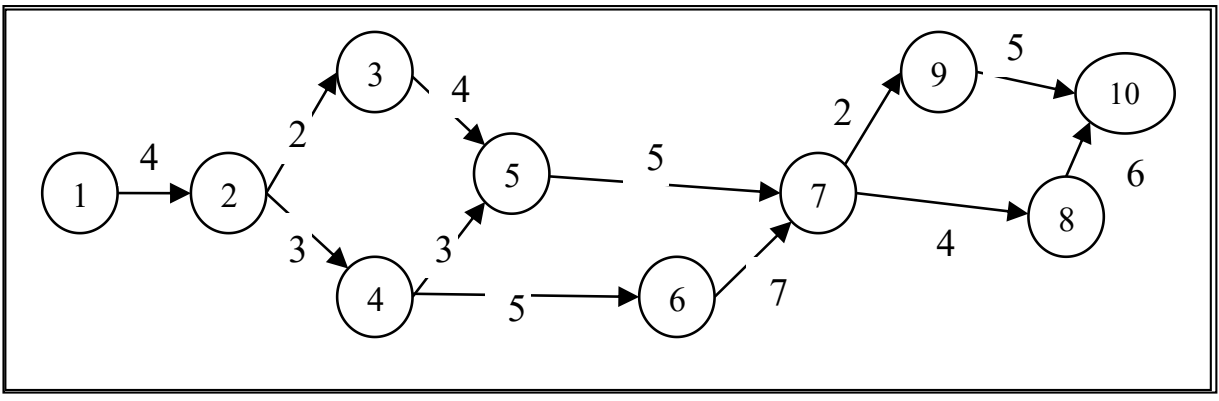

Fig. 1. Network diagram of the activities in environmental impact checklist for EMS process within the estimated time duration.

Therefore from the expected duration, it is observed that the critical path of the overall EMS process as provided in the network diagram at figure 1 is $1-2-4-6-7-8-10$. The expected variance of the length of the EMS process will be the sum of the expected variances of all the critical activities in environmental impact checklist for EMS process. Therefore, the expected variance of the length for implementation of EMS process = $0.11+0.11+0.44+0.11+0.44+0.44=1.65$ and the expected standard deviation of the completion time of the EMS process $=\sqrt{1.65}=1.29$

\section{Conclusion}

The present paper helps to reduce environmental impact for Indian infrastructure and construction projects. The planning and formulation technique is applied to implement EMS process for environmental impact checklist provided by MoEF \& CC in which each and every stages of impact are mitigated through Plan, do, check and act process and the EMS process was formulated using PERT and CPM techniques and it was identified that the expected time duration for implementation of EMS process for Indian large infrastructure and construction project was 29 days and approximately 30 days. The 
expected variance and standard deviation was also identified successfully. Hence, Planning and formulation of Environmental Management System for Indian Infrastructure project can reduce major environmental impact and also it can save time, cost and energy of any infrastructure and construction project.

\section{Acknowledgement}

The environment impact checklist was obtained from Manual on norms and standards for environment clearance of large construction projects. The Authors wish to thank Ministry of Environmental and forest climate change, Government of India for contributing the manual to the Nation's development in reducing the environmental impact due to large construction projects. The Author Akin C wish to thank Mr. Pitchi Rajan M, Assistant Professor and Mr. Hameedul Irshad, Assistant Professor, KCG College of Technology, Chennai, India for their friendly support.

\section{References}

1. Manual on norms and standards for environment clearance of large construction projects, (2006) New Delhi, India.

2. Sundaresan, V, Ganapathy Subramanian, K.S, Ganesan, K. (2000), "Resource Management Techniques", A.R. Publications, Tamil Nadu, India.

3. Gwen Christini, Michael Fetsko, and Chris Hendrickson, (2004), "Environmental Management Systems and ISO 14001 Certification for construction firms", Journal of construction engineering and Management, DOI: 10.1061/ (ASCE)07339364(2004)130:3(330).

4. Mohamed Marouen Amiri, Hédi Noubbigh, Kamel Naoui and Nouha Choura, (2015), "Environmental Management System: Environmental Impacts and Productivity", International Journal of Business and Management, doi:10.5539/ijbm.v10n11p107.

5. Aydemir Akyürek and Osman Nuri A ̆gdağ, (2017), "Evaluation of Environmental Management System Implementation in Construction Projects", European Scientific Journal, July 2017 /SPECIAL/ edition.

6. Report of the comptroller and Auditor general of India on environmental clearance and post clearance monitoring, (2016), Indian Audit and Accounts department, Ministry of Environment, forest and climate change, Government of India, Report No. 39 of 2016.

7. Xianbo Zhao and Natee Singhaputtangkul, (2015), "Effects of Firm Characteristics on Enterprise Risk Management: Case Study of Chinese Construction Firms Operating in Singapore", Journal of Management in Engineering, DOI: 10.1061/(ASCE)ME.19435479.0000434.

8. S. X. Zeng, C. M. Tam, Z. M. Deng and Vivian W. Y. Tam, (2003), "ISO 14001 and the construction industry: Survey in China", Journal of Management in Engineering, DOI: 10.1061/ (ASCE)0742-597X(2003)19:3(107). 